ISSN 0258-7122

Bangladesh J. Agril. Res. 37(3): 399-404, September 2012

\title{
POPULATION ABUNDANCE OF RED SPIDER MITE IN DIFFERENT VEGETABLES ALONG WITH ITS SPATIAL DISTRIBUTION AND CHEMICAL CONTROL IN BRINJAL (Solanum melongena L.)
}

\author{
N. K. DUTTA ${ }^{1}$, S. N. ALAM ${ }^{2}$, M. K. UDDIN ${ }^{3}$, \\ M. MAHMUDUNNABI ${ }^{4}$ AND M. F. KHATUN ${ }^{5}$
}

\begin{abstract}
Population abundance of red spider mite, Tetranychus urticae Koch., was studied in cucmber, ribbed gourd, bitter gourd, snake gourd, aroids and teasle gourd and efficacy of four new acaricides were tested against this pest in brinjal at the farmer's field of Norsingdi during 2009-2010. At the same time, the spatial distribution of this pest in brinjal crop was also studied. Results indicated that all the surveyed vegetables except bitter gourd were attacked by the mite with varying levels of infestation. However, the highest mite population per leaf was observed in brinjal (32.27) which was followed by cucumber (16.08) and teasle gourd (7.2). Mites were most densely populated in the lower canopy region in the brinjal plant. Among the tested acaricides, Lakad 1.8 EC (Abamectin) provided the highest (83.4\%) reduction of mite population over control, although the other acaricides also gave good control of this pest.
\end{abstract}

Keywords: Red spider mite, population abundance, spatial distribution, chemical control.

\section{Introduction}

Many vegetables are grown in Bangladesh throughout the year but most of them are prone to the attack of a variety of insect and mite pests. Among them, the red spider mite, Tetranychus urticae, has recently emerged as a major pest of vegetables causing serious economic loss. The outbreak of this pest in our country is assumed to be the consequences of frequent and indiscriminate use of toxic chemicals, especially pyrethroid insecticides by the vegetable growers (Dobson et al., 2002). Moreover, warm and dry weather is favourable for the multiplication and spread of this pest ( Jeppson et al., 1975). In India, it has been reported as one of the important pests of vegetable crops (Gupta, 1985; Singh et al., 1987) but during recent years, the out break of this pest in different vegetables in Bangladesh has become a serious problem for the growers. The first sight of infestation by red spider mite is usually chlorotic, stippled appearance on the leaves, although this may not be as apparent on thick-leaved plants. As the mites feed on the underside of the leaves, they remove leaf cell contents, including the chlorophyll that gives green colour of the leaves. Without

${ }^{1}$ Senior Scientific officer, ${ }^{2}$ Chief Scientific Officr (In-charge), ${ }^{3,485}$ Scientific Officer, Entomology Division, Bangladesh Agricultural Research Institute (BARI), Joydebpur, Gazipur, Bangladesh. 
the chlorophyll, those empty cells appear whitish or bronze. Heavily infested leaves turn completely pale, dry up, and fall off. Large populations can severely defoliate plants. Yield may be greatly reduced as the plants become weak and photosynthetic activity is seriously hampered. In many cases, our farmers are misguided by spraying insecticides to combat this pest and in a few cases, they spray traditional acaricides without having sufficient field control of this pest. Documentation of the population abundance and spatial distribution of this pest in vegetables and selection of newer acaricides would open up new scope for our farmers to combat spider mites in vegetable cultivation.

\section{Materials and Method}

Field survey was conducted in Norsingdi region during 2009-10 for studying the population abundance of red spider mite in brinjal, cucumber, snake gourd, teasle gourd, aroid, bitter gourd, and ribbed gourd. Three fields for each vegetable were randomly selected. In each field, 15 plants were also selected randomly. Mite population was counted from the 6 leaves of each plant with the help of a magnifying glass. Three surveys were conducted in each crop starting from the initiation of the pest attack at an interval of 10 days.

Furthermore, an experiment was conducted in the farmer's field at Norsingdi during 2009 to evaluate the efficacy of some new acaraicides against the red spider mites attacking brinjal. Brinjal seedlings of Shingnath variety were transplanted in a plot of $6 \mathrm{~m} \times 3.6 \mathrm{~m}$ having plant spacing of $60 \mathrm{~cm}$ and row spacing of $1 \mathrm{~m}$. The experiment was laid out in RCBD having three replications and 5 treatments including control. Standard agronomic practices were followed to raise the crop. Two sprays of each treatment were done at 15 days interval. The treatments were assigned as follows:

Spraying of Lakad 1.8 EC (Abamectin) @ $1.2 \mathrm{ml} /$ litre of water, spraying of Hisulphar 80WP (Sulphur) @ 4.0 g/litre of water, spraying of Talstar 2WP (Bifenthrin)@4.0 g/litre of water, spraying of Omite 57 EC (Propargite) @ 1.0 $\mathrm{ml} /$ litre of water anduntreated control.

All the acaricides were applied at the aforesaid doses by high volume knapsack sprayer. During application, care was taken to maintain the distance around $25 \mathrm{~cm}$ between the nozzle and plant parts. The whole plant was thoroughly covered by spray fluid. Sprayer was washed and cleaned after each acaricide spray.

In each plot, 6 plants from middle two rows were selected for data recording. Mite population was counted from the 6 leaves of each plant with the help of a magnifying glass. In each plant, two leaves were selected randomly from upper canopy, two from middle canopy, and two from lower canopy for counting mite 
population. Percent reduction of mite population over control was calculated by the following formula (Abbott, 1925):

$$
\mathrm{Pt}=\frac{P o-P c}{100-P C} \times 100
$$

Where, $\mathrm{Pt}=$ Corrected mortality, $\mathrm{Po}=$ Observed mortality and

Pc $=$ Control mortality.

Data were analyzed by using MSTAT-C software for analysis of variance following randomized completely block design (RCBD) and treatment means were separated by applying Duncan's Multiple Range Test (DMRT) at $1 \%$ level of significance.

\section{Results and Discussion}

\section{Population abundance of mites in different vegetables}

Results of the present study indicated that the host range of Tetranychus spp includes brinjal, cucumber, aroid, ribbed gourd, snake gourd, and teasle gourd. Fig. 1 indicates that among the surveyed vegetables, mean mite population per leaf was highest (32.27) in brinjal, which was followed by cucumber (16.08) and Teasle gourd (7.2). No mite population was recorded from bitter gourd. However, working on mite attack in different vegetables, Lanni Zhang (2008) recorded severe mite infestations on vegetables, such as snakebean, egg plant, and cucurbits.

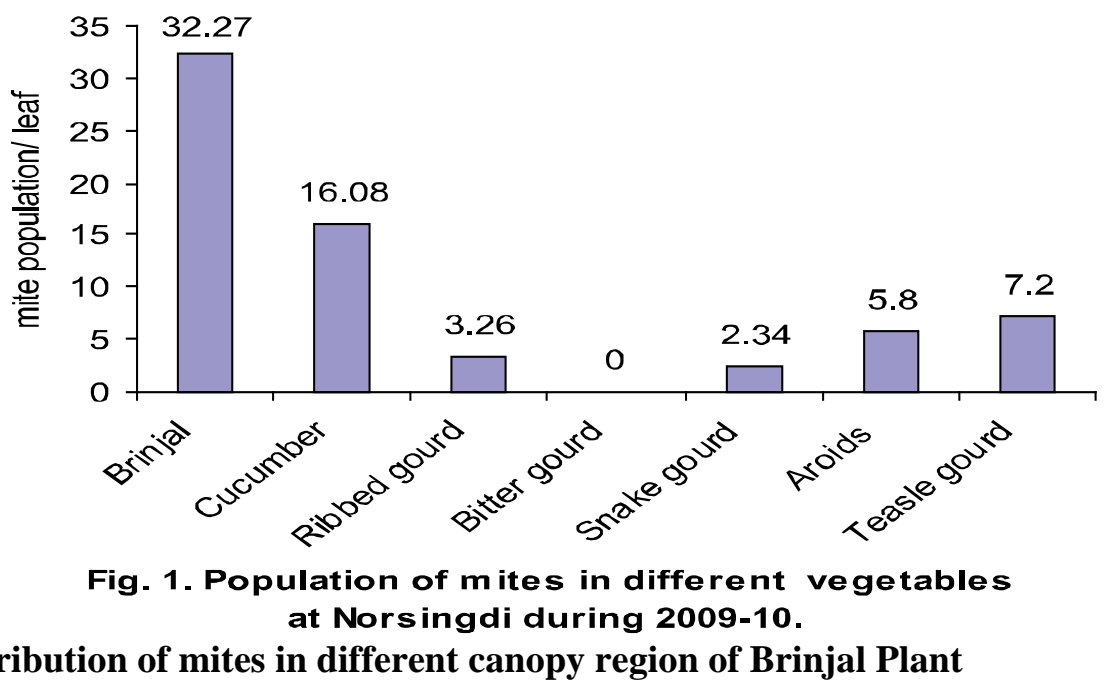

Fig. 2. revealed that red spider mite was most densely populated in the lower canopy (58.65\%) followed by middle canopy (29.81\%), and upper canopy 
(11.46\%). This result implies that mites were most densely populated in the older leaves. In a study on the spatial distribution of different mite species in strawberry plants, Fitzgerald et al. (2008) similarly reported that $T$. urticae was most abundant on older leaves. However, Dutta et al., 2011 observed reverse results while studying spatial distribution of mites in brinjal plant and reported that mite was most densely populated in the upper canopy (44.24\%) followed by middle (30.57\%) and lower canopy (25.19\%). This variation in result can be explained by the fact that mite population usually moves from lower canopy towards upper canopy when food reserve in the lower canopy becomes scanty.

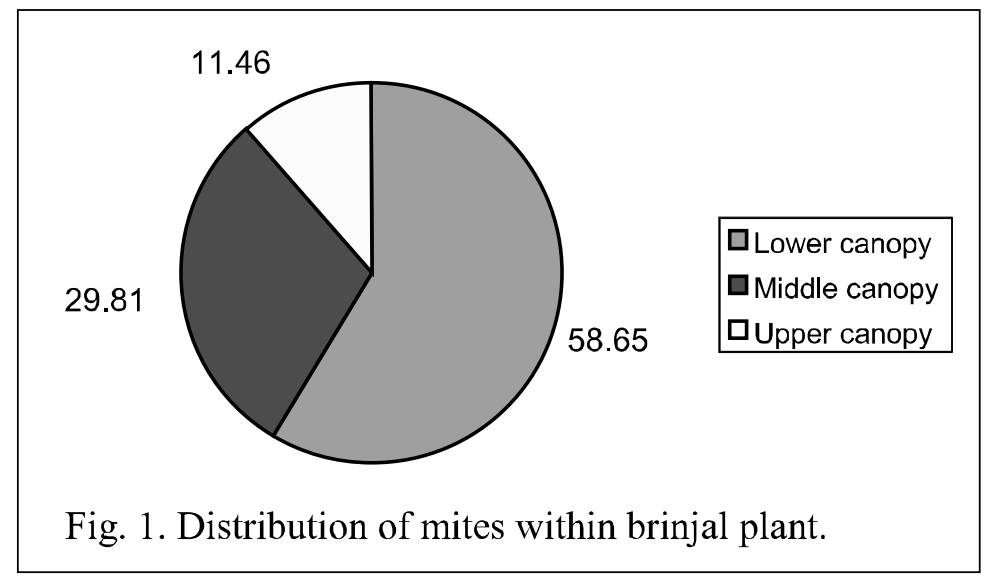

\section{Efficacy of different acaricides}

The results of the field efficacy test of different acaricides are presented in the Table 1. After 3 days of spraying (DAS), significantly the lowest mite population per leaf (18.02) was observed in Lakad 1.8EC treated plots followed by Omite 57 EC (30.98) and Hisulphur 80WP (32.21) treated plots. At 3 DAS, significantly the highest mite population per leaf was observed in control plots (68.96) which was significantly higher than those of all other acaricides tested. Again, after 7 days of spraying, the lowest mite population was recorded from the Lakad 1.8 EC (8.6 mites/leaf) treated plots followed by Omite 57 EC (14.92 mites/leaf) treated plots, Hisulphur 80 WP (17.32) and Talstar 2 WP (19.78), but there were no significant differences among them. The control treatments recorded significantly the highest mite population per leaf (65.01). It was observed (Table 1) that all the tested acaricides gave more or less satisfactory percent reduction of mite population over control at 7 DAS, Lakad (Abamectin)1.8 EC being provided the highest reduction $(83.40 \%)$ of mite population over control. The other acaricides in descending order of their efficacy were Omite 57 EC, Hisulphar 80WP, and Talstar 2WP. 
The findings of the present study is in conformity with Chandra Sekhar et al., (2007) who reported the highest reduction of mite population over control (92.25\%) when Abamectin at 2.7g a.i. per hectare was applied. Similarly, Dutta et al. (2011) obtained highest level of efficacy against brinjal mites by spraying Abamectin @ 1.2g/litre of water. De Klrek (1985) tested various chemicals in field for the control of the grape vine bud mite and found that chlorobenzilate (Akar) 50\% EC @ 50 ml/100 litre of water and propoxur (Unden) 20 \% EC @ $125 \mathrm{ml} / 100$ litre of water resulted in satisfactory control. He found the best results with three applications per season at 14 day intervals, starting at bud burst. While working with several acaricides against mites infestation in marigold Alam et al. (2007) found that dicofol 46.5 EC (Ethiosal) @ 1.5 \% was the most effective which reduced the mite population by $92.44 \%$ in 72 hours after treatment. However, the effectiveness of three acaricides should be further tested in different locations of other brinjal growing areas of Bangladesh.

Table 1. Efficacy of four selected acaricides sprayed against the red spider mites in brinjal at Norsingdi, 2009.

\begin{tabular}{|c|c|c|c|c|c|c|}
\hline \multirow{2}{*}{$\begin{array}{c}\text { Name of the } \\
\text { acaricides }\end{array}$} & \multirow[b]{2}{*}{ Dosage } & \multicolumn{3}{|c|}{$\begin{array}{c}\text { Mean no. of mite population/ } \\
\text { leaf }\end{array}$} & \multirow{2}{*}{$\begin{array}{c}\text { \% Reduction } \\
\text { of mite } \\
\text { population } \\
\text { at } 7 \text { DAS }\end{array}$} & \multirow{2}{*}{$\begin{array}{l}\text { \% Reduction } \\
\text { of mite } \\
\text { population } \\
\text { over control } \\
\text { at } 7 \text { DAS }\end{array}$} \\
\hline & & $\begin{array}{l}\text { Before } \\
\text { spray }\end{array}$ & $\begin{array}{l}03 \text { Days } \\
\text { after } \\
\text { spray }\end{array}$ & $\begin{array}{l}07 \text { Days } \\
\text { after } \\
\text { spray }\end{array}$ & & \\
\hline $\begin{array}{l}\text { Lakad 1.8EC } \\
\text { (Abamectin ) }\end{array}$ & $\begin{array}{l}1.2 \mathrm{ml} / \text { litre } \\
\text { of water }\end{array}$ & 61.58 & $18.02 \mathrm{c}$ & $8.6 \mathrm{c}$ & 86.03 & 83.40 \\
\hline $\begin{array}{l}\text { Hisulphar } \\
\text { 80WP } \\
\text { (Sulphar) }\end{array}$ & $\begin{array}{l}4 \mathrm{~g} / \text { litre of } \\
\text { water }\end{array}$ & 71.48 & 32.21 bc & 17.32 bc & 75.77 & 71.21 \\
\hline $\begin{array}{l}\text { Talstar 2WP } \\
\text { (Bifenthrin) }\end{array}$ & $\begin{array}{l}4 \mathrm{~g} / \text { litre of } \\
\text { water }\end{array}$ & 73.02 & $39.96 \mathrm{~b}$ & 19.78 bc & 72.91 & 67.81 \\
\hline $\begin{array}{l}\text { Omite 57EC } \\
\text { (Propergite) }\end{array}$ & $\begin{array}{l}1.0 \mathrm{ml} / \text { litre } \\
\text { of water }\end{array}$ & 70.93 & 30.98 bc & 14.92 bc & 78.97 & 75.01 \\
\hline Control & - & 77.25 & 68.96 a & $65.01 \mathrm{a}$ & 15.84 & - \\
\hline
\end{tabular}

DAS $=$ days after spray

Means having same letter(s) in a column are not significantly different at $\mathrm{P}>0.01$ followed by DMRT

\section{References}

Abott, W. S. 1925. A method of computing the effectiveness of an insecticide. J. Econ. Ent. 18: 265-267.

Alam, M.M., M. Jahan, K.S. Islam \& M. S. Ullah. 2007. Biology of red mite, Tetranychus bioculatus (Wood -Mason) infesting marigold and its control using three acaricides. Bangladesh J. Entomol. 17(1): 41-47. 
Chandra Sekhar, D., D. J. Reddy, S.J. Rahman, A. R. Reddy, V.V. Narendranath. 2007. Ecology and management of red spider mite Tetrnychus urticae Koch on Grape. In Proc. International symposium on grape production and processing.

Dobson. H., J. Copper, W. Manyangarirwa, J. Karuma, W. Chiimba. 2002. Integrated vegetable pest management: Safe and sustainable protection of small-scale brassicas and tomatoes-A hand book for extension staff and trainers in Zimbabwe. Published by NRI, University of Greenwich, UK.P.179.

De Klrek.1985.Chemical control of the grape vine bud mite, Eriophyes vitis (Pagenstecher). S. Afr. J. Ecol. Vitic., Vol. 6. No. 1. pp. 13-16.

Dutta, N.K., S. N. Alam, M. K. Uddin, M. Mahumudunnabi and M.F. Khatun. 2011. Incidence and spatial distribution of red spider mite, Tetranychus Urticae in brinjal and its chemical control. Bangladesh J. Entomol. 21(1):45-52.

Fitzgerald J., X. Xu, N. Pepper, M. Easterbrook, M. Solomon. 2008. The spatial and temporal distribution of predatory and phytophagous mites in field-grown strawberry in the UK. Exp. Appl. Acarol. 44(4):293-306.

Gupta, S.K. 1985. Hand Book of plant mites in India. Zoological Survey of India. Calcatta, 520.

Jeppson, L.R., H.H. Keifer and E. W. Baker. 1975. Mite injurious to economic plants. University of California Press, Berkeley, California. 614 pp.

Lanni Zheng. 2008. Biology and pest managemnt of spider mites. Fact Sheet . ENT 4. Nnorthern Teritory Government. China. p.3.

Singh, R.N., I.N. Mukherji, R.K. Singh and J. Singh. 1987. Evaluation of some pesticides against red spider mite Tetranichus ludeni Zacher on Cowpea. In. Proceeding 2. First Asia Pacific conference of Entomology, Thailand. 556-559. 